\title{
Using Behavioral Economics to Understand Premium Tax Credit Reconciliation
}

\author{
by Sarah Baggé
}

T

he Affordable Care Act provides advanced premium tax credits to millions of Americans to help with the cost of purchasing private health insurance on the new health insurance marketplaces. The amount of subsidy a family qualifies for is based on their projected income for the year ahead. However, since income is fairly unpredictable, some families end up qualifying for a larger tax credit when they do their taxes, while others end up with a smaller credit and must repay what they received throughout the year. In the first year of this reconciliation process, half of those who received advanced premium tax credits had to pay at least a part back. This outcome is consistent with recent literature in behavioral economics, which explores psychological, social, and cognitive influences on decision-making. This paper explores the reconciliation problem and possible approaches to reducing or eliminating it. 


\section{INTRODUCTION}

Advanced premium tax credits (APTC) are designed to make private health insurance affordable for low- and moderateincome Americans by reducing monthly premiums. The overwhelming majority of those enrolled in health insurance through the new marketplaces created by the Affordable Care Act receive some amount of APTC, with an average monthly subsidy of \$264 in 2014 for those enrolling through the federal marketplace (Office of the Assistant Secretary for Planning and Evaluation 2014, 5). Unlike other anti-poverty programs, APTC is based on projected income rather than current or past income. Enrollees who underestimate their income or fail to inform the marketplace of an increase must repay part or all of the credit when they file their taxes and their projected income is compared with their actual income. This process is called reconciliation.

This paper uses the insights of behavioral economics to explain the reconciliation problem and evaluates strategies for reducing the harm caused by reconciliation. I begin by laying out the basics of premium tax credit eligibility and the reconciliation process. Then, I use the insights of behavioral economics to explain the premium tax credit choices consumers are making. The paper concludes by describing several potential approaches to reducing or eliminating the reconciliation problem.
Figure 1: 2014 APTC Upper Income

Limits

\begin{tabular}{cc|}
$\begin{array}{c}\text { Household } \\
\text { size }\end{array}$ & $\begin{array}{c}\text { Upper income } \\
\text { threshold for APTC } \\
\text { in 2014 }\end{array}$ \\
\hline 1 & $\$ 45,960$ \\
2 & $\$ 62,040$ \\
\hline 3 & $\$ 78,120$ \\
\hline 4 & $\$ 94,200$ \\
\hline 5 & $\$ 110,280$ \\
\hline 6 & $\$ 126,360$ \\
\hline 7 & $\$ 142,440$ \\
\hline 8 & $\$ 158,520$ \\
\hline
\end{tabular}

Source: 400 percent of the 2014 Poverty Guidelines from the Office of the Assistant Secretary for Planning and Evaluation for HHS. Available online at: http://aspe.hhs. gov/2014-poverty-guidelines. Accessed January 10, 2016.

\section{ADVANCED PREMIUM TAX CREDITS}

The Affordable Care Act (ACA) created premium tax credits to subsidize the cost of health insurance for low- and moderateincome households. Under the program, households with incomes above the Medicaid eligibility threshold ${ }^{1}$ and equal to or below 400 percent of the Federal Poverty Level (FPL) may qualify for a refundable tax credit. As shown in Figure 1, 400 percent of FPL was $\$ 94,000$ for a family of four in $2014 .^{2}$

\footnotetext{
1 Thresholds vary among states and depending on factors such as age, pregnancy status, and whether the individual is a parent or guardian. The most common eligibility threshold for adults is 138 percent of FPL. See Kaiser Family Foundation Fact Sheet summarizing interstate variation at http:// files.kff.org/attachment/fact-sheet-where-are-statestoday-medicaid-and-chip-2.

2 Because reconciliation occurs the year after APTC is received, all figures in this paper are for 2014 , the only tax year for which reconciliation has occurred.
} 
The IRS sets a sliding scale of expected contributions - the percent of a household's annual income they are expected to pay for health insurance before qualifying for a subsidy. In 2014, expected contributions ranged from 2 percent for those with incomes below 150 percent of FPL to 9.5 percent for those with incomes above 300 percent of FPL. ${ }^{3}$ The premium tax credit is the amount a household would pay in excess of the household's expected contribution for the second-lowest cost plan at the silver level of coverage (Fernandez 2014, 8-9). Plans are placed into four levels (bronze, silver, gold, and platinum) based on the percentage of healthcare costs covered by the plan for the average enrollee. Silver level plans cover, on average, 70 percent of healthcare costs, and the enrollee pays 30 percent out of pocket (Fernandez 2014, 1). month) before qualifying for a premium tax credit. The cost of the second least expensive silver plan available to the family was $\$ 908$ per month. ${ }^{4}$ Since the cost of this plan was higher than the household's expected contribution, they qualified for the difference of $\$ 692$ per month for their APTC. The Allens could have chosen to reduce their premiums by $\$ 692$ per month or waited to receive $\$ 8,309$ as a refund on their taxes for 2014 in early 2015. They could also have opted for any combination of the two. For example, they could have applied $\$ 400$ per month $(\$ 4,800$ total) to their premium and received the remaining $\$ 3,509$ as a refund.

Premium Tax Credit $=$ Second Lowest Cost Silver Plan Premium - Expected Contribution

Those eligible for APTC must choose to:

1. Have the full amount of the tax credit applied to the cost of their premium during the coverage year; or

2. Receive the credit as a refund on their taxes for the coverage year; or

3. Take any amount as APTC and the remainder as a refund.

For example, consider the hypothetical Allen family of three, ages 57, 53, and 22. In 2014, they lived in Chicago, Illinois and had a predicted income of $\$ 40,000$. This income put them at approximately 205 percent of FPL, meaning they were expected to contribute about 6.5 percent of their household income to their premiums (a total of $\$ 2,587$ annually or $\$ 216$ per

3 The IRS updates expected contribution amounts each year.

\section{RECONCILIATION}

The amount of APTC given to a tax household is based on their projected income for the coverage year. If the fictional Allen family enrolled in coverage at the beginning of the first open enrollment period in October 2013 for a health plan starting on January 1, 2014, they did so based on their best estimate of what their income would be in 2014. When the family filed their taxes for 2014, the amount of APTC they had taken was reconciled with the amount they qualified for based on their actual 2014 income. If the Allens took less APTC than they were eligible for, the remainder reduced their taxes for the year or was returned to them as a refund. If

$4 \quad$ Numbers based on estimates provided by healthcare.gov for 2014 plan costs. Accessed December 7, 2014. 
the family took more APTC than they were eligible for, they had to pay part or all of the amount back on their taxes.

Through the reconciliation process, families who either project their income incorrectly or experience a change in income or household size they do not report could end up with a higher tax bill. For example, if one of the Allens received a raise of \$2.75 per hour in March and the other got a holiday bonus of $\$ 2,000$, their total income would be $\$ 6,840$ greater than their original projection. Then, if they realized they could not claim their 22-yearold son on their 2015 taxes because his income was above the income limit for dependents, their household size would decrease. If the Allens failed to report these changes to their marketplace to have their tax credit adjusted, they would end up receiving $\$ 3,852$ more in APTC than they were actually eligible for. Figure 2 summarizes the differences between the Allen family's projected and actual situation for 2014.

In order to minimize the impact of reconciliation in situations like this, the ACA caps the amount that a household has to repay based on income, as shown in Figure 3. These caps place some limits on reconciliation, but still leave enrollees open to substantial financial risk. If the Allen family ended 2014 at 302 percent of FPL, instead of 205 percent, their total premium tax credit overpayment would be $\$ 3,852$. However, because of the cap, they would only have to pay back $\$ 2,500$. In 2014, 463,000 taxpayers (a quarter of those who had to repay) reached a repayment cap. The caps prevented repayment of $\$ 394$ million, an average of $\$ 851$ per taxpayer who reached a cap (Koskinen 2016, 3).

This protection does not, however, extend to those whose actual income ends up exceeding the 400 percent of FPL limit for the premium tax credit. In these cases,

Figure 2: Example of Projected vs. Actual APTC

\begin{tabular}{lcc} 
& Projected & Actual \\
\hline Income & $\$ 40,000$ & $\$ 46,840$ \\
Household Size & 3 people & 2 people \\
Monthly APTC & $\$ 692$ & $\$ 371$ \\
Total Annual APTC & $\$ 8,304$ & $\$ 4,452$
\end{tabular}

Figure 3: APTC Repayment Caps by Income

\begin{tabular}{lcc}
\multicolumn{1}{c}{ FPL levels } & Individual & Family \\
\hline Less than 200 percent & $\$ 300$ & $\$ 600$ \\
At least 200 percent but less than 300 percent & $\$ 750$ & $\$ 1,500$ \\
At least 300 percent but less than 400 percent & $\$ 1,250$ & $\$ 2,500$ \\
400 percent or more & No cap & No cap
\end{tabular}


repayments are not capped and households must repay the full amount of APTC. Modeling done using Survey of Income and Program Participation (SIPP) data predicted repayments ranging from $\$ 2,000$ to $\$ 4,000$ among those expected to owe a repayment whose 2014 income exceeded 400 percent FPL. (Cox et al. 2015, 6-7). ${ }^{5}$

\section{CHALLENGES FOR APTC ACCURACY}

Ninety-two percent of those who received APTC did not receive the correct amount (Koskinen 2016, 2-3), which is unsurprising given the difficulties this population faces projecting and updating income. The first and biggest challenge is making an accurate prediction of income because APTC recipients are likely to experience changes in income during the year. The second challenge is reporting changes when they occur. Marketplaces have struggled to keep up with reports of changes, and enrollees may still owe a repayment even after their subsidy has been recalculated.

APTC was designed to benefit those without employer coverage, including those who are self-employed, work part-time, or have seasonal jobs. However, income from these types of jobs is unpredictable: a

5 Those with lower starting incomes would face higher repayments because their monthly tax credit amounts would be higher. However, only 6 percent of those starting in the 100 to 200 percent FPL bracket are expected to owe a full repayment as compared to 57 percent of those starting between 300 and 400 percent FPL because of the relative amounts that income would have to increase to exceed 400 percent FPL (Cox et al. 2015, 7). The IRS has not released data about repayment amounts for those who exceeded the 400 percent threshold for APTC eligibility change in hours or working a second parttime job could add hundreds or thousands of dollars to annual income. Models run before initial reconciliation data was available suggested the population eligible for APTC would experience significant income volatility (Cox et al. 2015, Jacobs et al. 2013, Sommers and Rosenbaum 2011). A simulation of the subsidy-eligible population in California showed that 38 percent of households were expected to have an increase in income of greater than 10 percent in a year. If these households took the full amount of APTC and failed to report changes, all would have to make repayments, with a median repayment of $\$ 857 .{ }^{6}$ Even in the best-case scenario modeled by the researchers (where all changes in income were reported), 27 percent of those receiving subsidies would be subject to repayments with a median repayment of \$332. ${ }^{7}$ As shown in Figure 4, a significant number of those who started off eligible for this subsidy were projected to become ineligible by the end of the year when their household incomes would exceed 400 percent of FPL (Jacobs et al. 2013, 1541-2). These individuals would have to repay the full cost of their APTC.

A simulation of the 2014 tax season using SIPP data predicted that only 5 percent of potentially tax credit-eligible households would have no change in income, while 51 percent would have an

$6 \quad$ The actual average repayment amount so far has been close to what was modeled at $\$ 860$ (Koskinen 2016, 2).

7 Reporting all changes does not eliminate the need for subsidy repayment. The recalculated APTC amount does not take into account APTC already received during the year. If an enrollee reports an income increase, has her tax credit adjusted and continues to take the full amount of APTC, she may still owe on the higher amount of APTC received at the beginning of the year. 
Figure 4: Predicted Changes in Annual Income of California Health Insurance Exchange Subsidy Recipients, 2018-19, as a percentage of the Federal Poverty Level

\begin{tabular}{ccccccc}
\hline \multicolumn{8}{c}{ Final income as a percent of poverty } \\
$\begin{array}{c}\text { Family income at } \\
\text { enrollment as a } \\
\text { percent of poverty }\end{array}$ & $<\mathbf{1 0 0}$ & $\mathbf{1 0 1 - 1 3 8}$ & $\mathbf{1 3 9 - 2 0 0}$ & $\mathbf{2 0 1 - 2 5 0}$ & $\mathbf{2 5 1 - 3 9 9}$ & $>\mathbf{4 0 0}$ \\
\hline$<\mathbf{1 0 0}$ & $70 \%$ & $18 \%$ & $6 \%$ & $3 \%$ & $2 \%$ & $1 \%$ \\
\hline $\mathbf{1 0 1 - 1 3 8}$ & $30 \%$ & $30 \%$ & $23 \%$ & $8 \%$ & $7 \%$ & $2 \%$ \\
\hline $\mathbf{1 3 9 - 2 0 0}$ & $14 \%$ & $16 \%$ & $38 \%$ & $17 \%$ & $11 \%$ & $4 \%$ \\
$\mathbf{2 0 1 - 2 5 0}$ & $9 \%$ & $7 \%$ & $26 \%$ & $29 \%$ & $23 \%$ & $6 \%$ \\
$\mathbf{2 5 1 - 3 9 9}$ & $5 \%$ & $4 \%$ & $11 \%$ & $13 \%$ & $47 \%$ & $19 \%$ \\
$>\mathbf{4 0 0}$ & $13 \%$ & $11 \%$ & $25 \%$ & $17 \%$ & $26 \%$ & $9 \%$ \\
\hline
\end{tabular}

Replicated from Jacobs et al. 2013. California Simulation of Insurance Markets (CalSIM) model, version 1.7 (Note 11 in text); Survey of Income and Program Participation (Note 12 in text), 2004-05 and 2008-09.

income increase and 44 percent would see income drop. Those with incomes below 200 percent of FPL would be the most likely to have to repay (Cox et al. 2015, 4-5). While actual income fluctuation data from 2014 is not available, it is likely such variations drove at least some of the repayment volume.

The difficulties involved in reporting income changes pose the second major challenge to APTC accuracy. Obstacles to change reporting can be split between difficulties enrollees have in reporting changes and problems marketplaces have experienced with processing changes that are reported. Marketplace enrollees are required to report changes in income within 30 days. However, surveys indicate some enrollees may not be aware they are required to report changes. In a national survey done by the Kaiser Family Foundation in April and May of 2014, only 46 percent of marketplace enrollees reported receiving a subsidy, which was less than half of the actual number according to HHS (Hamel et al. 2014).
For those who do report changes, the report may not result in an immediate adjustment of the level of subsidy or completely protect enrollees from repayment. The enrollee may need to provide proof of the change either electronically or in person and wait for the new information to be processed. The marketplaces have had trouble keeping up with the volume of income documents and change reports (Goldstein and Somashekar 2014). Even when a reported change is processed promptly, marketplaces do not take into account APTC already received that year, so repayment may still be necessary. For example, consider an enrollee who received $\$ 200$ per month in APTC until May, when her income changed so that she was eligible for only $\$ 100$ per month. The marketplace would change her APTC to $\$ 100$, effective in June, but would not account for the $\$ 500$ overpayment of APTC that had already occurred that year ( $\$ 100$ per month for the first five months of the year). To avoid repayment, this consumer should receive only $\$ 29$ per month in APTC. 


\section{EXPERIENCE}

Results from 2014 show that only 8 percent of those who received APTC got their APTC amount "just right" and were not entitled to a refund or required to make a repayment. ${ }^{8}$ Half of those who received APTC in 2014 took more than they were eligible for, with an average repayment of $\$ 860 .{ }^{9}$ Forty-one percent took less APTC than they were eligible for, thus receiving an average of $\$ 640$ in premium tax credits (Koskinen 2016, 2). The majority of those who faced repayment did not have to repay the full value of the credit. Of those who owed a repayment, 61 percent still received a tax refund (Koskinen 2016, 2).

\section{THE PROBLEM WITH RECONCILIATION}

One reason APTC reconciliation repayments are problematic is because they may reduce the impact of anti-poverty tax credits. Many low- and moderate-income families rely on large refunds from tax credits like the Earned Income Tax Credit (EITC) and Child Tax Credit. The EITC alone can equal several months of wages. Large refunds offer many households their

8 These numbers reflect returns filed for the 2014 tax year the IRS processed by the end of October, 2015. Every year, millions of taxpayers receive extensions that allow them until October 15 to file. Some of these returns were likely still being processed when these numbers were collected. As of the end of October, only 67 percent of those who received APTC had filed and reconciled their APTC. The bulk of those who did not reconcile their APTC filed without reporting the APTC (Koskinen 2016, 3 ). It is possible that those who did not reconcile their APTC are systematically different from the population who filed on time.

9 A quarter of those who had to repay APTC hit a repayment cap. The caps protected these taxpayers from an additional average repayment of $\$ 851$. only opportunity to save, repay debts, or make significant investments, such as purchasing a vehicle (Adams, Einav, and Levin 2009, 57-9). In an in-depth study of EITC recipients in Boston, HalperinMeekin et. al found that families allocated 87 percent of their refunds to bills, repaying debts, investments in assets and mobility like car repairs and educational expenses, and savings. The remaining 13 percent was split between treats (for example, gifts for children) and tax preparation fees (2015, 63-5). Most families in the study placed such a high value on a large refund that they chose to maximize it by not taking any personal allowances, effectively increasing their tax burden throughout the year $(2015,86)$. H\&R Block's analysis of returns filed during the 2014 tax season showed that the refunds of those who had to repay their APTC were reduced by an average of 33 percent (H\&R Block 2015). For households counting on large refunds, this represents a serious blow to their ability to catch up and save at tax time.

These numbers are not likely to improve much as consumers gain familiarity with the ACA. The complexities of withholding, deductions, and credits in federal and state tax law mean that few understand what determines their refund amount. Almost none of the 115 households that Halperin-Meekin et. al. interviewed could identify the amounts of specific payments and credits on their tax documents (2015, 72). Without understanding the impact of repayments, consumers are unlikely to make changes that could protect them from repayment. 


\section{BEHAVIORAL ECONOMICS PREDICTION}

Given the threat of repayment, why don't more enrollees protect themselves by making a generous prediction of income, promptly reporting changes in income, or taking less than the full amount of APTC? While these may seem like logical steps, the real choices people make often differ from what a rational choice model would predict. For decades, psychologists and economists have documented how human decision-making consistently violates rational principles in certain situations. The field of behavioral economics focuses on these deviations from rational behavior and describes how people use biases and rules of thumb called heuristics to make decisions. This section uses insights from behavioral economics to explain observed marketplace enrollee behavior regarding APTC.

Daniel Kahneman describes human decision-making as divided between two

Figure 5: Monthly Premium Plan

Display for Federally-Facilitated

Marketplace

\section{Blue Cross and Blue Shield Bronze PPOSM 006}

\section{Bronze PPO}

National Provider Network

Plan ID: 36096 IL0790030

ESTIMATED MONTHLY PREMIUM

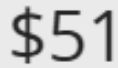

Number of people covered: 1

Premium before tax credit: $\$ 262$ systems. System I is intuitive, unconscious, and automatic. It uses heuristics to make decisions quickly and is what we use to make decisions in most situations. System II closely resembles the rational actor: conscious, slow, effortful thinking that weighs all the available information before making a decision. Because System II requires high cognitive resources, we engage System II infrequently (Schleifer 2002, 1082-4).

Heuristics likely play a large role in how consumers choose to use their APTC. For example, the lowest cost heuristic directs consumers to select the lowest premium cost option, even when other costs such as deductibles and coinsurance are higher (Ericson and Starc 2012, 493-7). Initial data from the health insurance marketplaces suggest that low premium prices are a strong predictor of plan choice. Plans are organized into four coverage levels (bronze, silver, gold, and platinum) based on the percentage of healthcare costs the enrollee will have to pay compared to what the plan will pay, on average. The lower tiers (bronze and silver) offer cheaper monthly premiums but higher out-of-pocket costs to use services. Eighty-five percent of those enrolled in 2014 chose a bronze or silver plan. (Office of the Assistant Secretary for Planning and Evaluation 2014, 8).

The way information is displayed provides cues to consumers about what should be most important in making their decisions. Designers can highlight a certain plan feature by making it visually prominent or setting the default order that plans display (Kingsley and Quincy, 2012, 5-6). As shown in Figure 5, marketplace plan displays emphasize premiums with the full amount of the subsidy already applied. ${ }^{10}$ Selecting a plan based on the full 
subsidy amount may make it more difficult later to commit to a greater monthly expense in order to create an APTC buffer.

Status quo bias is a second heuristic that could push consumers enrolling in marketplace plans to take the full amount of APTC. In most marketplaces, the full APTC amount is applied to a plan by default (Center on Budget and Policy Priorities 2014). Enrollees are allowed to change this amount, but many studies of retirement savings plans have shown that people have a strong bias towards the default value (Beshears et al. 2009, 170-3). Consumers would be unlikely to actively choose less than the full APTC.

Even consumers who consider the possibility of owing a large repayment at tax time may opt to take the full amount of APTC. Kahneman's prospect theory shows that people are risk-seeking when faced with losses. Kahneman asked study participants to choose between a certain loss of $\$ 500$ or a 50 percent chance of a $\$ 1,000$ loss, most opt for the risk of the $\$ 1,000$ loss (Kahneman 2011, 280). The choice of APTC amount can be seen as a potential choice between two losses: the certainty of losing a small amount each month by forgoing some of your APTC versus the risk of a large loss in the future from the reconciliation repayment. Prospect theory predicts most will take the risk on the larger future loss.

Risk-seeking behavior can also be explained by framing the APTC choice in terms of rewards instead of losses. People tend to over-value rewards received immediately and undervalue rewards that will happen in the future, a behavior called hyperbolic discounting (Bernartzi,

10 Taken from Healthcare.gov 2014 plan cost estimator. Accessed December 5, 2014.
Peleg, and Thaler 2007, 8-10). While reconciliation ensures that a marketplace enrollee who forgoes all or part of his APTC now will receive the full amount as a tax refund or reduction in tax liability, she will likely place a higher value on starting to receive the benefit now than waiting to receive it on her taxes.

The application and plan selection process could also lead to decision fatigue, which may exacerbate the biases described above. Choosing the APTC amount is the last decision a consumer makes after completing the complex application and choosing a plan. In 2014, consumers were offered an average of 30 health plans from three insurers (Office of the Assistant Secretary for Planning and Evaluation 2014, 4). ${ }^{11}$ Plans vary by premiums, network, deductible, cost-sharing amounts, out-ofpocket maximums, and benefit coverage. While a high number of choices might seem to make shoppers better off, it can actually decrease social welfare by overwhelming the decision-maker (Rice 2013, 438-9). Studies have shown that poverty depletes cognitive control, making low-income consumers enrolling in coverage with APTC particularly vulnerable (Spears 2011, 32-3).

A final reason that marketplace enrollees may be likely to face repayment is because of the transaction costs of reporting changes to income. In addition to contacting the marketplace, enrollees may need to provide proof of the change either electronically or in person and wait for the new information to be processed. Evidence from other public benefits programs shows the transaction costs involved with gathering and providing documentation,

11 Consumers are expected to face even more plan choices in 2015, with an average of 4 carriers and 37 plans per county. 
including time, money, and inconvenience can deter some from participating or maintaining their cases (Remler and Glied 2006, 72).

\section{POLICY OPTIONS}

Behavioral economics shows that people are particularly bad at making good choices when the costs of a choice are immediate but the benefits are in the long term (Thaler and Sunstein, 75). The federal government and the marketplaces can use the insights of behavioral economics to help their enrollees avoid reconciliation repayments. This section explores three broad policy approaches with several variations that would eliminate or reduce the problem of high reconciliation repayments.

\section{ELIMINATE RECONCILIATION}

The first approach is to change the administration of the subsidies to eliminate reconciliation. This could be done one of four ways. The first option is to not reconcile APTC. Enrollees would estimate their income and pay the subsidized cost of their premiums without the threat of repayment. If income increases, the marketplace would not ask enrollees to repay their subsidies. This would align the treatment of APTC with many other means-tested benefits, including Medicare Parts B and D, college student aid, and stimulus payments made through the tax code (Burman, Mermin, and Ramirez 2015, 6). This solution would also make the treatment of APTC consistent with cost-sharing reductions, the other marketplace subsidy available to those with incomes below
250 percent of FPL. While this approach would solve the problem of reconciliation undermining anti-poverty tax measures, it would also create significant cost and program integrity problems. Without reconciliation, enrollees would have the incentive to underestimate their income for the upcoming year to receive a higher credit, and the IRS would have no way of recovering these costs.

A second alternative for eliminating reconciliation is to remove the advance option for the premium tax credit so that instead of receiving the subsidy each month, enrollees would receive a large credit when they file their taxes. Under this scenario, the premium tax credit would operate like other tax credits for lowincome taxpayers such as the American Opportunity and Saver's credits, which provide incentives when taxes are filed. APTC would not be the first advanceable tax credit for low-income taxpayers to be made non-advanceable. The EITC was once advanceable, an option that was eliminated in 2011 after a GAO study showed that only 3 percent of those eligible used the advanced option and most low-income taxpayers preferred to receive the EITC in a lump sum (GAO 2007, 9). However, unlike the advanced EITC, APTC has proven to be very popular. Eighty-five percent of enrollees with subsidies in 2014 reported that they would not be able to afford their insurance premiums without APTC (Hamel et al. 2014). Removing the option to apply the subsidy to monthly premium would likely lead some to drop their coverage.

A third approach is to convert APTC from a tax credit to a non-tax benefit based on current rather than projected income, such as SNAP or Medicaid. Instead of 
asking enrollees to predict their income a year in advance, subsidy amounts would be based on current income and adjusted throughout the year as enrollees reported changes to their income. This would have the added benefit of simplifying and aligning eligibility determinations between Medicaid and APTC and reducing the risk of gaps in coverage due to churning between the two programs. Using monthly income, however, comes with its own set of challenges. Program rules for SNAP and Medicaid require enrollees to report even slight changes in income, a burdensome and often unrealistic expectation for those working jobs with variable hours. A study of SNAP cases found that lowincome families whose incomes vary greatly are more likely to forgo available benefits (Moffit and Riber 2009, 18-20). Updating eligibility monthly would also increase the likelihood that this population would experience gaps in coverage due to temporary periods of ineligibility.

The final option is to base tax credit eligibility on previous years' income without requiring reconciliation at the end of the year. Medicare uses a similar method: if an enrollee's most recent tax return shows an income above the subsidy threshold, he must pay an additional premium. Medicare allows a safe harbor for those who can prove that their income has declined due to a change in income or family size (Zelenak 2011, 733-8). A similar approach could be applied to APTC. Since the subsidy would be based on information available at the time APTC was calculated, there would be no need for reconciliation. Like all other options to eliminate reconciliation, using prior year tax information would increase the cost of the subsidies because the subsidy could only be increased based on income changes throughout the year, not decreased.

\section{REDUCE THE IMPACT OF RECONCILIATION}

Instead of eliminating reconciliation, the marketplaces could focus on reducing the impact of reconciliation by decreasing the size of repayments. The original maximum repayment in the ACA was $\$ 250$ for individuals and $\$ 400$ for families, and extended up to those with final incomes of 500 percent FPL to minimize the possibility of having to repay the full tax credit (Zelenak 2011, 727). Congress raised the repayment caps twice, lowered the income level at which caps applied from 500 percent FPL to 400 percent, and created a scaled structure (requiring higher repayment from those with higher incomes). Returning these caps to their original levels would preserve some of the incentive to estimate income accurately and report changes in income while also reducing the repayment amount and allowing impacted households to keep more of their refunds. However, lowering the caps would increase the risk that households would intentionally underestimate their incomes, counting on caps to limit their tax liability and allowing them to keep a large portion of the overpayment.

\section{REDUCE THE LIKELIHOOD OF RECONCILIATION}

Short of changing the nature of the marketplace subsidies or repayment caps, there are several approaches that focus on helping enrollees make the best decisions 
about the amount of subsidy to take in advance or to encourage timely reporting of changes. Most of these efforts so far have focused on educating consumers about their option to take less than the full amount of the subsidy at the time of enrollment. Quincy, Kleimann, and Kingsley tested educational materials that highlighted the potential for repayment and the option to receive the credit at tax time instead of in advance. When they asked focus group participants how they would take a tax credit if they had fluctuating income, half said that they would opt to take the credit at tax time, while the other half said they would use the advance option to keep up with monthly expenses (2013, 30-31). However, as Schliefer explains, educational approaches to changing behavior tend to rely on people using their System II thinking to make a decision. More effective messages target System I (Schleifer 2002, 1088-9).

Default values are a powerful signal to consumers using System I to make decisions. Marketplaces can use the power of the default value by setting the default amount of APTC to less than the full amount. Seeing a default value of a partial tax credit could also alert enrollees to the option of taking a partial amount of APTC, which has been difficult for consumers to understand in consumer testing (Quincy, Kleimann, and Kingsley 2013, 27-28). For example, in the District of Columbia in 2014, enrollees saw the full amount of

Figure 6: APTC Amount Selection Screen from DC Marketplace Application

How much of your Advance Premium Tax Credit would you like to use towards your Monthly Premium?

Your Monthly Cost: $\$ 540.34$

Total Advance Premium Tax Credit Available: $\$ 405.00$

This will reduce your premium paid each month to your insurance plan.

\author{
All my eligible amount \\ - $85 \%$ of my eligible amount \\ None in advance \\ I would like to specify my amount
}

The remaining amount can be collected when you file your taxes

Monthly Tax Credit

344.25

Why take less than all? 
the subsidy when shopping for plans but only 85 percent when it came to making the final APTC decision (Executive Board of the District of Columbia Health Benefit Exchange Authority 2013). As shown in Figure 6, enrollees must take action to take a higher or lower amount. ${ }^{12}$

The literature on default values suggests that most consumers will not act to override a default (Kingsley and Quincy, 2012, 10-12). The District of Columbia's default has not followed this pattern, with 87 percent taking more than the default and the remaining 13 percent evenly split between those who took the default and those who took less than the default (Executive Board of the District of Columbia Health Benefit Exchange Authority 2015). This may be due to the fact that by the time consumers see the 85 percent value, they have already seen the full tax credit amount on several screens. Displaying the default amount first and allowing users to change it might increase the uptake of the default. A more aggressive default would not show consumers the full amount they were eligible for and prevent them from applying the full amount of the tax credit. This approach, however, would likely require a state to apply for a Section 1332 State Innovation waiver as it would require the exchange to override key ACA eligibility provisions (Benshoof 2015).

Another possibility would be to make use of peoples' greater willingness to accept restrictions in the future than in the present. For example, the Save More Tomorrow program, which offered employees the choice to designate an increased percentage of a future raise to

12 Taken from DC Health Link application process. Accessed on December 9, 2014. retirement savings, showed much higher rates of savings than when employees were asked to increase contributions in the present (Bernartzi and Thaler 2007, 100). In the APTC context, enrollees could be offered the choice to voluntarily reduce their APTC amount at a later date in order to provide a buffer against repayment. When enrolling, for example, enrollees could opt to take a lower percentage of the available APTC the following year when they would be auto-renewed into their plan. This would build an increasing buffer to protect against repayment.

Efforts to increase income change reporting might also reduce the amounts of reconciliation repayments. Marketplaces could send reminders throughout the year prompting enrollees with APTC to report income changes. Tax experts Burman, Mermin, and Ramirez have also recommended allowing reconciliation of APTC on a monthly rather than an annual basis. This would better protect enrollees with significant income fluctuations because it would limit repayment to only the months in which the increase occurred (2015, 6-7). However, this would be very complex to administer.

\section{CONCLUSION}

As the IRS continues to analyze the experience of the first tax season with APTC and as the focus begins to shift to the 2015 tax season, reconciliation will continue to have implications for a range of anti-poverty programs beyond healthcare. Since APTC is a federal benefit with eligibility set at the national level, most of the policy options that would substantially eliminate or reduce reconciliation require Congressional action. At a minimum, the 
original repayment caps and limits from the ACA should be restored to protect taxpayers from the highest repayments. Congress should also consider eliminating reconciliation by using prior-year income to calculate APTC amounts and allowing consumers to provide proof of decreases in income to increase the subsidy. This would allow those with year-to-year income reductions to receive higher subsidies while also protecting those whose incomes increase from repayment.

Even without Congressional action, state-based marketplaces and the federal marketplace can take steps to protect enrollees from reconciliation. Used effectively, default values can steer consumers towards providing themselves with an APTC cushion while maintaining the monthly premium reductions that are key to affordability. State-based marketplaces will have new flexibility to make changes with the introduction of State Innovation waivers in 2017. These waivers allow the federal government to waive ACA requirements as long as the changes do not increase the federal deficit. States should explore ways to modify their marketplaces that both protect affordability and minimize reconciliation.

The interaction between reconciliation and key anti-poverty tax credits is an area of particular concern. Policymakers must ensure that reconciliation does not erode the effectiveness of other areas of the tax code in providing a much-needed annual income boost. The purpose of APTC is to make health insurance more affordable for low- and moderate-income households. It must do so by adding to and not working against other anti-poverty programs.

The opinions expressed in this article are the author's own and do not reflect the views, approval, or endorsement of the DC Health Benefit Exchange Authority.

\section{REFERENCES}

Adams, William, Liran Einav, and Jonathan Levin. 2009. "Liquidity Constraints and Imperfect Information in Subprime Lending." American Economic Review 99:49 - 84. Accessed December 7, 2014. Doi: 10.1257/aer.99.1.49.

Beshears, John, James J. Choi, David Laibson, and Brigitte C. Madrian. 2009. “The Importance of Default Options for Retirement Savings Outcomes: Evidence from the United States." in Social Security Policy in a Changing Environment, edited by Jeffrey Brown, Jeffrey Liebman, and David A. Wise, 167-195. Chicago: University of Chicago Press.

Benshoof, Galen. "Nudging Towards a Smoother Tax Season." Health Affairs. Accessed August 15, 2015. http://healthaffairs.org/blog/2015/07/29/nudging-toward-asmoother-tax-season/. 
Bernartzi, Shlomo, Ehud Peleg, and Richard H. Thaler. 2007. Choice Architecture and Retirement Savings Plans. Social Science Research Network. Accessed February 25, 2016. http://164.67.163.139/Documents/areas/fac/accounting/Benartzi_ ChoiceArchitecture.pdf.

Bernartzi, Shlomo and Richard H. Thaler. 2007. "Heuristics and Biases in Retirement Savings Behavior." The Journal of Economic Perspectives 21:81-104. Accessed December 7, 2014. doi: 10.1257/jep.21.3.81.

Blavin, Frederic, Stan Dorn, and Jay Dev. 2014. "Using Behavioral Economics to Inform the Integration of Human Services and Health Programs Under the Affordable Care Act.” Prepared for the Office of the Assistant Secretary for Planning and Evaluation, Department of Health and Human Services. Washington, D.C.: Urban Institute. http://aspe.hhs.gov/hsp/14/IntegrationProject/rpt_ BehavioralEconomics.pdf.

Burman, Leonard, Gordon Mermin, and Elena Ramirez. 2015. Tax Refunds and Affordable Care Act Reconciliation. Washington, D.C.: Tax Policy Center of the Urban Institute and Brookings Institution. Accessed October 15, 2015. http:// www.urban.org/sites/default/files/alfresco/publication-pdfs/2000164-taxrefunds-and-the-affordable-care-act-reconciliation.pdf.

Center for Budget and Policy Priorities. 2014. Health Reform: Designing a Marketplace - Eligibility and Enrollment Question 10. Washington, D.C.: Center on Budget and Policy Priorities. Accessed on December 9, 2014. http://apps.cbpp.org/ DesigningAMarketplace/.

Cox, Cynthia, Anthony Damico, Gary Claxton, Rosa Ma, and Larry Levitt. 2015. Repayments and Refunds: Estimating the Effects of the 2014 Premium Tax Credit Reconciliation. Washington, D.C.: Kaiser Family Foundation. Accessed October 25, 2015. http://files.kff.org/attachment/issue-brief-repayments-and-refundsestimating-the-effects-of-2014-premium-tax-credit-reconciliation.

Ericson, Keith Marzilli and Amanda Starc. 2012. "Heurisitics and Heterogeneity in Health Insurance Exchanges: Evidence from the Massachusetts Connector." American Economic Review: Papers \& Proceedings 2012 102:493-497. Accessed November 29, 2014. doi: 10.1257/aer.102.3.493.

Executive Board of the District of Columbia Health Benefit Exchange Authority. "Final Minutes for Monday, April 13, 2015." Accessed August 16, 2015. http://hbx. dc.gov/sites/default/files/dc/sites/hbx/event_content/attachments/Final\%20 Executive\%20Board\%20Minutes\%2041315.pdf. 
. "Resolution to establish a default setting for the amount of advanced premium tax credit displayed to users during plan selection.” Passed May 9, 2013. Accessed December 6, 2014. http://hbx.dc.gov/sites/default/files/dc/sites/ Health\%20Benefit\%20Exchange\%20Authority/publication/attachments/ Resolution-DefaultAPTC.pdf.

Fernandez, Bernadette. 2014. Health Insurance Premium Tax Credits in the Patient Protection and Affordable Care Act. Washington, D.C., Congressional Research Service. Accessed on January 3, 2016. https://www.fas.org/sgp/crs/misc/R41137. pdf.

Goldstein, Amy and Sandhya Somashekhar. "Federal Health-care Subsidies May be Too High or Too Low for 1 Million Americans." Washington Post (Washington, D.C.), May 16, 2014. Accessed December 6, 2014, http://www.washingtonpost. $\mathrm{com} /$ national/health-science/federal-health-care-subsidies-may-be-too-high-ortoo-low-for-more-than-1-million-americans/2014/05/16/8f544992-dd14-11e38009-71de85b9c527_story.html.

Government Accountability Office. 2007. Advance Earned Income Tax Credit: Low Use and Small Dollars Paid Impede IRS's Efforts to Reduce High Noncompliance. Washington, D.C., Government Accountability Office. Accessed on October 19, 2015. http://www.gao.gov/new.items/d071110.pdf.

Halperin-Meekin, Sarah, Kathryn Edin, Laura Tach, and Jennifer Sykes. 2015. It's Not Like I'm Poor: How working families make ends meet in a post-welfare world. Oakland: University of California Press.

Hamel, Liz, Mira Norton, Larry Levitt, Gary Claxton, Cynthia Cox, Karen Pollitz, and Mollyann Brodie. 2014. Survey of Non-Group Health Insurance Enrollees. Washington, D.C.: Kaiser Family Foundation. Accessed on October 25, 2015. http://kff.org/health-reform/report/survey-of-non-group-health-insuranceenrollees/.

H\&R Block. "H\&R Block's Final ACA Stats: Refunds Impacted for Most Who Received Advance Tax Credit.” 2015. Accessed on August 15, 2015. http://newsroom. hrblock.com/hr-blocks-final-aca-stats-refunds-impacted-received-advance-taxcredit/.

Jacobs, Ken, Dave Graham-Esquire, Elise Gould, and Dylan Roby. 2013. "Large Repayments of Premium Subsidies May be Owed to the IRS if Family Income Changes are not Promptly Reported." Health Affairs 32:1538-1545. Accessed on October 29, 2014. Doi: 10.1377/hlthaff.2013.0186. 
Kahneman, Daniel. 2008. Thinking, Fast and Slow. New York: Farrar, Straus, and Giroux, 2011.

Kaiser Family Foundation. 2011. Reconciliation of Advance Payments for Health Insurance Subsidies. Menlo Park: Kaiser Family Foundation. Accessed on November 29, 2014. http://kaiserfamilyfoundation.files.wordpress. com/2013/01/8154.pdf.

Kingsley, Barbra and Lynn Quincy. 2012. Choice Architecture: Design Decisions that Affect Consumers' Health Plan Choices. Rockville: Kleinmann Communication Group, Inc. and Consumers' Union. Accessed on February 25, 2016. http:// consumersunion.org/pdf/Choice_Architecture_Report.pdf.

Koskinen, John. 2015. "Preliminary Results from the 2015 Filing Season Related to Affordable Care Act Provisions." (Letter to Congress, Washington, D.C.), 1-4. Accessed on August 15, 2015. http://www.irs.gov/pub/irs-utl/ CommissionerLetterlwithcharts.pdf.

2016. "Updated Results for the 2015 Filing Season Related to Affordable Care Act Provisions." (Letter to Congress, Washington, D.C.), 1-6. Accessed on January 10, 2016. https://www.irs.gov/pub/newsroom/irs_letter_aca_ stats_010816.pdf.

Moffitt, Robert, and David C. Ribar. 2009. Variable Effects of Income Volatility on Food Stamp Participation. Washington, D.C., US Department of Agriculture. Accessed on October 19, 2015. http://naldc.nal.usda.gov/download/32813/PDF.

Office of the Assistant Secretary for Planning and Evaluation. 2014. "Health Insurance Marketplace: Summary Enrollment Report.” Washington, D.C.: Department of Health and Human Services. Accessed on November 29, 2014. http://aspe. hhs.gov/health/reports/2014/marketplaceenrollment/apr2014/ib_2014apr_ enrollment.pdf.

.2014. "Premium Affordability, Competition, and Choice in the Health Insurance Marketplace, 2014." Washington, D.C.: Department of Health and Human Services. Accessed on February 26, 2016. https://aspe.hhs.gov/sites/ default/files/pdf/76896/2014MktPlacePremBrf.pdf.

.2014. "Health Plan Choice and Premiums in the 2015 Health Insurance Marketplace." Washington, D.C.: Department of Health and Human Services. Accessed on December 5, 2014. http://aspe.hhs.gov/health/reports/2015/ premiumReport/healthPremium2015.pdf. 
Policy Perspectives / Volume 23

Quincy, Lynn, Susan Kleimann, and Barbra Kingsley. 2013. "Helping Consumers Understand the New Premium Tax Credit." Washington, D.C.: Consumers Union. Accessed on October 29, 2014. http://consumersunion.org/wp-content/ uploads/2013/05/Understanding_The_Premium_Tax_Credit.pdf.

Remler, Dahlia, and Sherry Glied. 2006. "What Other Programs Can Teach Us: Increasing Participation in Health Programs." American Journal of Public Health, 93:67-74. Accessed on January 3, 2015.

Rice, Thomas. 2013. “The Behavioral Economics of Healthcare." The Annual Review of Public Health, 34:431-37. Accessed on December 7, 2014. Doi: 10.1146/ annurev-publhealth-031912-114353.

Schleifer, Andrei. 2002. "Psychologists at the Gate." Review of Thinking, Fast and Slow, by Daniel Kahneman. Journal of Economic Literature 50:1080-1091.

Spears, Dean. 2011. "Economic Decision-making in Poverty Depletes Behavioral Control." The B.E. Journal of Economic Analysis and Policy 11:1-42. Accessed on December 7, 2014. http://riceinstitute.org/wordpress/wp-content/uploads/ downloads/2011/12/depletion-published.pdf.

Sommers, Benjamin D. and Sara Rosenbaum. 2011. "Issues in Health Reform: How Changes in Eligibility May Move Millions Back and Forth Between Medicaid and Insurance Exchanges." Health Affairs 30:228-236. Accessed November 30, 2014. Doi: 10.1377/hlthaff.2010.1000.

Thaler, Richard H. and Cass R. Sunstein. Nudge: Improving Decisions about Health, Wealth, and Happiness. New York: The Penguin Group.

Zelenak, Lawrence. 2011. "Choosing Between Tax and Non-tax Delivery Mechanisms for Health Insurance Subsidies.” Tax Law Review 65:723-748. Accessed December 7, 2014. http://heinonline.org/HOL/LandingPage?handle=hein. journals $/$ taxlr65\&div=34\&id $=$ \&page $=$. 
SARAH BAGGÉ received her Master's of Public Policy from George Washington University with a focus on social and health policy in December. Since 2013, she has implemented the Affordable Care Act in the District of Columbia as a part of the Health Benefit Exchange Authority (HBX), where she currently serves as Assistant Director of Marketplace Innovation, Policy, and Operations. Prior to joining HBX, Sarah was a health policy analyst at Families USA, a national healthcare advocacy organization. She has also worked to improve access to public benefits for low-income families as a fellow with the Congressional Hunger Center and as an AmeriCorps member. Sarah has a B.A. in International Relations from Wheaton College. She lives in the District with her husband and an impressive collection of kitchen toys.

\section{ACKNOWLEDGEMENTS}

The author thanks Dr. Gerald Brock, Dr. Michael Wiseman, Dr. Sanjay Pandey, her Associate Editor Nick Hugh, and the whole Policy Perspectives editorial team for their thoughtful feedback. She also thanks her husband, Mark, for the encouragement, edits, and late-night snacks that made this article (and her MPP) possible. 